\title{
Process Portals - Architecture and Integration
}

\author{
Thomas Puschmann, Rainer Alt \\ Institute of Information Management \\ University of St. Gallen \\ St. Gallen, Switzerland \\ \{Prename.Surname\}@unisg.ch
}

\begin{abstract}
Process portals support the inter-organizational networking of businesses. They define function and content on the basis of the customer process and make them available to the user via a role-based and personalized interface. In spite of the growing relevance of process portals, their use in most businesses is still only at the beginning. A consistent architecture and integration model can help businesses with the introduction of process portals. This article argues that the available approaches to architecture from the relevant literature and from practice do not adequately address process portal requirements, and develops an extended architecture model. The steps required to implement this architecture are described in this article using the example of the Automobile Group.
\end{abstract}

\section{Introduction}

\subsection{Business Networking through Process Portals}

Businesses use many different portals for interorganizational collaboration with suppliers and customers [16]. From a business perspective a portal groups together all the services of different businesses for a customer process and thus provides it with a single point of contact. The goal is to set up process portals which link individual roles with intra-organizational and inter-organizational applications [23]. Process portals are understood as webbased, personalizable and integrated systems to access internal and external applications which support customer processes and implement graphical and/or audiovisual front-end integration [23]. The main potentials are to be found in improved customer retention, improved process efficiency and cost reduction through the integrated availability of information [12]. Examples of possible fields of application are:

- Intra-organizational Integration. Deutsche Telekom AG is aiming to establish a group-wide employee portal with its portal MyTeamNet. In future the corporation wants to integrate the existing subgroup portals such as T-Online Intranet and the Employee
Self-Service portal by means of the new portal. Deutsche Telekom wants to achieve this by defining web services. In future, this should make it easier for portal operators to reuse services for authentication, single sign-on, personalization, etc.

- Inter-organizational Integration. Robert Bosch $\mathrm{GmbH}$ links its inter-organizational processes with customers and suppliers through SupplyOn and Covisint. In future, the applications from the areas of product development, procurement, supply chain planning and execution, sales and service which are required for this purpose will be integrated centrally through one portal. This will mean, for example, that buyers at DaimlerChrysler will be able to configure their own individual process portals composed of different suppliers.

\subsection{Benefits of a Process Portal Architecture}

The forecasts of numerous analysts show that the use of portals has grown continuously since early 1998. IDC, for example, anticipates an increase in sales volume for portal software from USD $455 \mathrm{~m}$ in the year 2001 to USD $3.1 \mathrm{bn}$ in 2006 [20]. Unlike the sales volume for standard business management software, which in 2001 showed only a slight increase of $4.3 \%$ over the previous year, the worldwide market for portals grew by $59 \%$ to a total USD $709 \mathrm{~m}$ in the same year. This growth is also confirmed by an estimate of the Butler Group which assumes sales of USD 4.07bn for 2006 [2]. In spite of this growth potential the number of businesses already using process portals to communicate with customers, suppliers and employees has been small up to now. According to a study by Roth [27], the level of penetration in early 2002 was in the region of $25 \%$, but will rise to up to $90 \%$ by 2006 . Similar figures are predicted by Forrester with a utilization rate of just $20 \%$ for 2001 [12], while in 2002 over one third of the world's 3500 largest companies were planning several portal projects between 2002 and 2005. The reasons for this are on the one hand falling costs for setting up portals, and on the other more portal functions and the im- 
proved integration capability of standard business management software.

In many companies, particularly those which operate globally, a proliferation of portals in different business units and/or geographical regions is already apparent today (cf. [25], [35]). However, this contradicts the actual aim of process portals, namely to group together applications and information through a role-based user interface. Architectures constitute a tool for structured introduction and the systematic consolidation of existing systems, as already shown in the context of ERP [25]. This applies equally in the case of portals (cf. [2], [25], [35]). Portal architectures basically possess two functions. On the one hand they provide transparency in respect of existing elements in order to reveal improvement potentials. On the other hand, standardizing the structural elements of a portal architecture can facilitate communication and documentation.

Alongside these two basic functions, portal architectures offer businesses additional quantitative and qualitative benefits which are reflected, for example, in an improved integration capability and a reduction in introduction costs for portals. These potentials can be assigned to the general critical success factors of time, costs, quality and flexibility, and based on concrete metrics to test their effectiveness. Table 1 shows possible potentials and metrics for portal architectures (cf. also [13]).

\begin{tabular}{|c|c|c|}
\hline $\begin{array}{l}\text { Critical } \\
\text { Success } \\
\text { Factors }\end{array}$ & Potentials & Metrics \\
\hline Time & $\begin{array}{l}\text { - Higher transparency } \\
\text { - Reduction in manual interfaces } \\
\text { - Availability of know-how } \\
\text { - Faster integration of new appli- } \\
\text { cations } \\
\text { - Simple maintenance }\end{array}$ & $\begin{array}{l}\text { - Number of manual } \\
\text { interfaces } \\
\text { - Number of stan- } \\
\text { dards used }\end{array}$ \\
\hline Costs & $\begin{array}{l}\text { - Higher level of standardization } \\
\text { - Utilization of synergies be- } \\
\text { tween business units in a group } \\
\text { of companies } \\
\text { - Avoidance of bad investments } \\
\text { - Reduction in costs relating to } \\
\text { subsequent reconfiguration }\end{array}$ & $\begin{array}{l}\text { - Introduction costs } \\
\text { - Integration costs } \\
\text { - Maintenance costs } \\
\text { - Number of media } \\
\text { discontinuities } \\
\text { - Number of inter- } \\
\text { faces }\end{array}$ \\
\hline Quality & $\begin{array}{l}\text { - Greater user acceptance } \\
\text { - Higher quality of new applica- } \\
\text { tions developed } \\
\text { - Greater security }\end{array}$ & $\begin{array}{l}\text { - } \text { Number of com- } \\
\text { plaints } \\
\text { - Error rate } \\
\text { - Performance } \\
\text { - Availability }\end{array}$ \\
\hline $\begin{array}{l}\text { Flexibil- } \\
\text { ity }\end{array}$ & $\begin{array}{l}\text { - Easier to extend and modify to } \\
\text { suit new requirements } \\
\text { - Easier internationalization } \\
\text { - Easier migration } \\
\text { - Interoperability } \\
\text { - Scalability }\end{array}$ & $\begin{array}{l}\text { - Maintenance costs } \\
\text { - Time and effort for } \\
\text { upgrades } \\
\text { - Ratio of decen- } \\
\text { trally to centrally } \\
\text { stored master data }\end{array}$ \\
\hline
\end{tabular}

Table 1. Potentials of Portal Architectures

\subsection{Research Method}

The portal architecture developed in this article is based on the concept of action research, which derives results in five steps [4]. The problem is first defined jointly by practice and science (1). Researchers structure the problem and develop proposals for designing the operational reality (2). Theoretical knowledge and practical experience provide the fundamental principles. Researchers and practitioners then examine the proposals and refine them (3). Practice applies the proposals, i.e. it designs the operational reality in accordance with these recommendations (4). Finally, the results are examined jointly and the proposals further developed (5).

The problem for the portal architecture relates to requirements which emerged from projects with nine international companies during the period 1998 to 2002 (1). The architecture and the procedural model developed for integration are based on existing theoretical models and practical project experience (2) obtained in a multilateral project between April 2000 and March 2002. The participating companies were DaimlerChrysler AG, Deutsche Telekom AG, emagine GmbH, ETA SA, Hewlett-Packard Company, Hoffmann-La Roche Ltd., Robert Bosch $\mathrm{GmbH}$, Triaton $\mathrm{GmbH}$, and SAP AG. The architecture models were examined and adapted in workshops with the partner company representatives and the solutions developed then applied in the projects (3). The architecture model for process portals is based on the findings from the projects (4). The architecture model was validated in the projects which in some cases are still ongoing as well as in numerous discussions with interviewees from business practice (5).

\section{Architecture}

\subsection{Review of Existing Approaches}

Portals have been discussed as a concept for personalized access to information and applications since 1998 [2]. While initial approaches to portals concentrated on the integration of intra-organizational content, the process portals considered here focus on inter-organizational integration of applications. They thus provide internal and external users with role-based, process-oriented access to a comprehensive set of coordinated added-value services. This they support by providing inter-organizational services such as security, personalization, etc. [6]. The benefit for the portal user is the back-end integration of these services.

Portals are by definition information systems (IS) as they support the user in his or her individual process with information production and communication [6]. Since the 1980s companies have been using information system architectures (IS architectures) to structure and document 
their IS. A widely used approach to IS architecture is the client/server architecture $(\mathrm{C} / \mathrm{S}$ architecture) which splits IS into the three logic levels of presentation, application functionality and data (cf. e.g. [21], [31]). On the basis of this model the existing approaches in the relevant literature and in practice show the following focus:

\begin{tabular}{|c|c|c|c|c|c|}
\hline & \multicolumn{2}{|c|}{$\begin{array}{c}\text { Architecture } \\
\text { Reach }\end{array}$} & \multicolumn{3}{|c|}{$\begin{array}{c}\text { Architecture } \\
\text { Model }\end{array}$} \\
\hline & 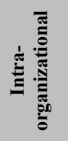 & 焉 & 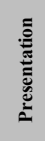 & 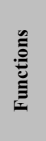 & 气ूँ \\
\hline \multicolumn{6}{|c|}{ Approaches in Literature } \\
\hline ARIS [38] & $\bullet$ & $\not$ & $\not$ & $\bullet$ & $\bullet$ \\
\hline E-business architecture [18] & $\not 8$ & $\bullet$ & $\mathscr{8}$ & $\bullet$ & 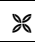 \\
\hline Inter-enterprise architecture [11] & 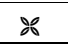 & $\bullet$ & 8 & $\bullet$ & 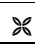 \\
\hline inter-organizational integration [19] & $\mathscr{8}$ & $\bullet$ & 8 & $\bullet$ & $\bullet$ \\
\hline Integrated information systems [25] & $\bullet$ & $\ddot{8}$ & $\ddot{8}$ & $\bullet$ & 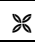 \\
\hline Total information systems management [28] & $\bullet$ & $\ddot{x}$ & 8 & $\bullet$ & $\bullet$ \\
\hline \multicolumn{6}{|c|}{ Approaches by Analysts } \\
\hline Butler Group enterprise portals [3] & $\bullet$ & $\ddot{x}$ & $\bullet$ & $\ddot{8}$ & $\ddot{8}$ \\
\hline Corporate portals [6] & $\not 8$ & $\bullet$ & $\bullet$ & 8 & 8 \\
\hline Ovum enterprise portals [29] & $\bullet$ & $\ddot{8}$ & $\bullet$ & $\ddot{8}$ & $\ddot{x}$ \\
\hline Uberportal [30] & $\bullet$ & $\not 8$ & $\bullet$ & $\mathscr{8}$ & $\mathscr{8}$ \\
\hline \multicolumn{6}{|c|}{ Approaches by Software Manufacturers } \\
\hline IBM WebSphere portal [17] & 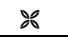 & $\bullet$ & $\bullet$ & $\bullet$ & 8 \\
\hline Plumtree corporate portal [32] & $\bullet$ & $\mathscr{8}$ & $\bullet$ & $\mathscr{8}$ & $\mathscr{8}$ \\
\hline TIBCO ActivePortal [43] & $\not 8$ & $\bullet$ & $\bullet$ & $\not 8$ & 88 \\
\hline SAP enterprise unification portal [9] & $\not 8$ & $\bullet$ & $\bullet$ & $\bullet$ & 8 \\
\hline
\end{tabular}

Table 2. Comparison of Approaches to Architecture in Literature and Practice

- Architecture Reach. Most of the approaches described in the literature are aimed at the intraorganizational field (see Table 2). The approaches of software manufacturers and analysts do take interorganizational processes with customers and suppliers into account, but frequently lack the required product neutrality. The connection with customer and supplier systems on the one hand and the heterogeneity of architectures on the other calls for openness and an inter-organizational integration capability on the part of the underlying portal architectures.

- Architecture Model. With regard to client/server architecture, the existing models in the relevant literature and in practice frequently only describe the business management functionality of applications. Portal architectures, however, call for an integrative analysis of the levels presentation, application functionality and data which extends beyond the limits of systems and organizations [10]. The added value of portals, after all, is derived from the backend integration of the application functionality and data offered.

\subsection{Development of an Architecture for Process Portals}

The goal of this article is to develop an interorganizational architecture model for process portals, which takes into account the deficits mentioned above. A model of this kind is shown in Figure 1. It is the result of the requirements derived from the portal projects mentioned in Section 1.3. In accordance with the action research approach, this development was preceded by an analysis of the software manufacturers' architectures evaluated in Section 2.1, Table 2 (cf. [15], [26], [34], [8]) and of the approaches to be found in the available literature and provided by analysts (cf. [2], [6], [5], [12], [3], [24]). The developed architecture model was then successively validated in projects. One of these projects at the Automobile Group is described in detail in Section 4 and shows the implementation of the architecture.

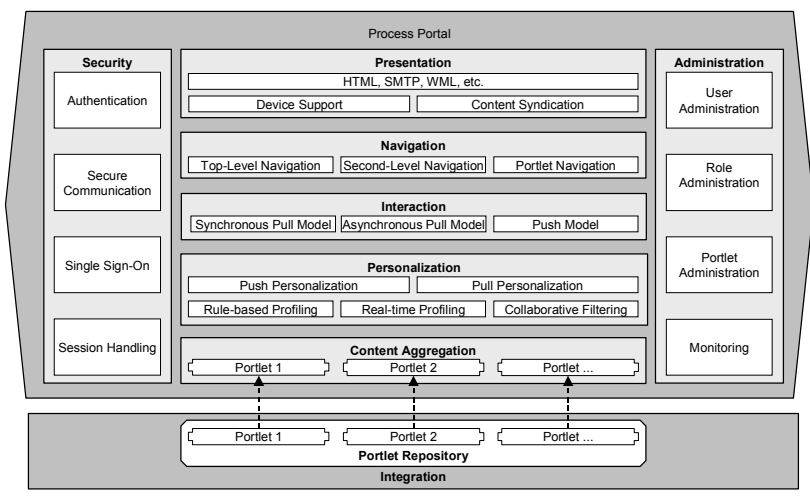

Figure 1. Architecture of Process Portals

The modules of this architecture offer the following functions: if a user accesses a portal, it checks the user's authenticity, authorizes access to the integrated applications, e.g. through single sign-on, and regulates communication between client and portal (security). On access, the portal checks whether a user has already logged on and whether a user profile has been saved (personalization). On the basis of these personalization data the portal extracts the portlets from the content sources and aggregates them to form a portal page (content aggregation). These portlets depict individual functions of applications on the portal page. They can therefore be defined as reusable function modules which offer access to all the applications [14]. The integration layer described here is limited to the portlets which are directly integrated into the portal. Further relevant modules of the integration architecture such as Enterprise Application Integration (EAI) and web services form part of the inter- 
services form part of the inter-organizational integration architecture in Section 3. Based on the underlying personalization data, the portal outputs the content objects to the respective device (presentation). Depending on the underlying interaction model, it either actively requests the data from the user or the portal operator sends these to the user (interaction). The user can utilize the different navigation models for browsing in the portal (navigation). The administration component manages the individual user groups in the portal, defines roles and adds or removes portlets (administration).

\section{Integration}

Portals integrate the functions of different, mostly heterogeneous applications and place these in the context of specific business processes. Unlike conventional architectures, however, portal architectures integrate applications at the level of the user interface as well as at the level of functionality and data. An interface which is homogeneous but integrated across various applications replaces the specific front-ends of these applications. Process portals implement this form of integration by combining the technologies shown with dark gray shading in Figure 2.

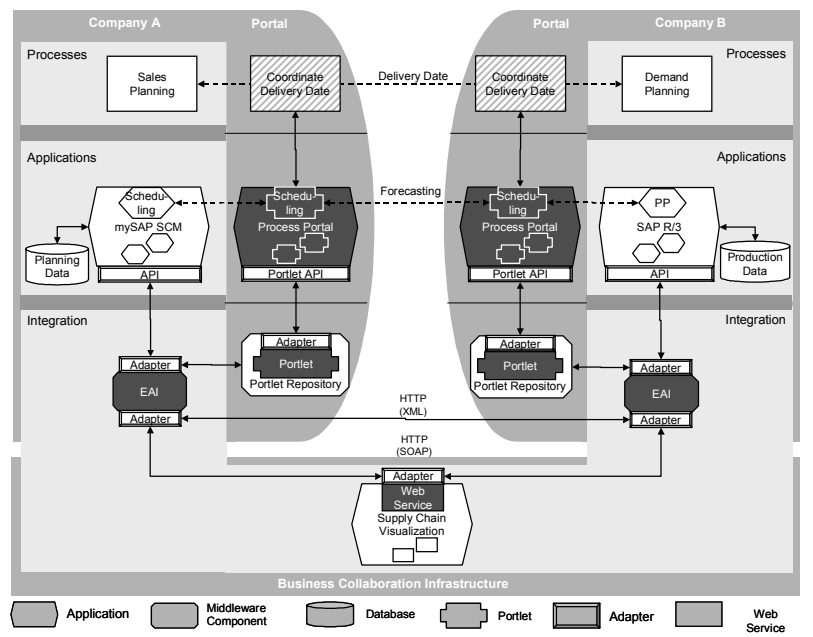

Figure 2. Modules of an Integration Architecture for Portals

As the integration architecture in Figure 2 shows, the portal integrates the business process-related functionality of business management systems by means of portlets. Portlets thus cover the presentation level in the model of the client/server architecture (see section 3.1). While portlets primarily relate to human-machine integration, web services address machine-machine communication and integrate applications with application functions which are integrated into the portal via the portlets (see section 3.2). The architecture described here realizes data integra- tion using EAI systems (see section 3.3). These offer functions for the mapping and transportation of heterogeneous data from the different applications involved.

\subsection{Presentation Integration: Portlets}

From the point of view of the web browser, portlets are web applications [14], which are developed using any programming language and exchange data on the basis of standards. Examples range for simple functions such as collecting and sending e-mails to more complex functions such as displaying a parts list or determining all the transactions and sales of a specific customer in a given year . Several portlets can be positioned per portal page. There are basically two possibilities for integrating portlets into a portal page:

- Browser-side Integration. This type of integration uses iFrames. It involves extensions of frame technology which allow content from a separate HTML page to be placed in any rectangular area embedded in a portal page. The integration to form a complete page is performed on the browser side. This option is advisable above all in the case of portlets which frequently change.

- Server-side Integration. Server-side integration is based on Server Side Include technology (SSI). Here, an HTML page is compiled by the web server from a number of individual areas (rendering) and then sent to the browser complete. This technology is used primarily when the portlets do not change very often.

Server-side integration based on SSI can in turn be implemented in two different versions:

- Parsed HTML/XML. Since HTML pages, unlike XML documents, are unstructured, they are only of limited suitability for structured data processing, as to be found, for example, in databases. For this reason, tags have to be set which define the start and end of each headline block so that HTML pages can be read. Within the blocks special tags mark the start and end of each headline. In the case of structured XML sources, parsed XML technology extracts headlines from these content sources. The language XPath can be used to localize headline blocks and fields.

- Passthrough HTML/XML. With passthrough HTML/XML, the portal presents content from sources in a portal page without reading content in headlines. The portal page either shows the content as it is stored in the original source or transforms it into a predefined layout by means of an XSLT template. The difference between these two versions is that the portal integrates the HTML page without a layout 
template since in the case of HTML presentation elements are already contained in the code.

\subsection{Function Integration: Web Services}

A major design element of integration architecture is web services. From a technical point of view, web services are aimed at communication between loosely linked software components [32]. The web service standards SOAP, WSDL and UDDI provide the framework for inter-organizational and cross-application system-to-system communication through remote function calls. At the same time, however, they disregard the presentation integration functions which are relevant to portlets (cf. [7], [30]). In contrast with the usual intra-organizational and locally implemented portlets, web services represent inter-organizational portlets which, however, lack a concrete presentation function [14]. If businesses want to integrate web services into their portals they therefore have two types of web services to fall back on [30]:

- Data-oriented web services provide XML documents as output. The portal is responsible for the proper processing and formatting of the data. This form of integration requires the programming of individual interfaces in order to be able to depict specific web service operations and presentation elements in the portal. For the purposes of implementation, portlets can be used which are extended to include web service functions and presentation elements.

- Presentation-oriented web services incorporate presentation and interaction logic. With this type of integration the web service provides presentation fragments which are already standardized to ensure a uniform appearance in the portal. Integration in the portal is based on a portlet proxy which processes the web service operations locally and transfers them to the web service. An implementation of this type of web service is provided by the standard "Web Services for Remote Portals" [30].

The differences between these two types of portlet affect their integration into a portal. Intra-organizational portlets are implemented locally and are typically closely meshed with the portal application. The implementation of web services without standardized user interfaces is also performed locally as each web service typically requires its own proxy code for integration. It is only when the web service interface for presentation and interaction logic is standardized and a generic portlet proxy defnined that this local implementation will become superfluous.

\subsection{Data Integration: Enterprise Application Integration}

While portlets only allow reading access to the data of different heterogeneous applications, EAI systems such as e.g. the IBM Websphere Business Integration Suite or the mySAP Exchange Infrastructure provide coordinated writing access to different systems and their data (cf. [17], [18], [33]). At the technical level, therefore, EAI systems and portlets interact differently with the data source. Portlet adapters are based on metadata which establish a relationship between different objects of individual applications, such as e.g. a customer number, by harmonizing the data models. Unlike portlets, EAI systems transform the data formats of a source application into the format of a target application (mapping). In so doing they create a writing access to different data sources. EAI systems are to be seen as a complementary element to portlets as they expand the functionality of portals to include the possibility of performing transactions through the portal. As an extension of conventional middleware which primarily addresses the concerns of a harmonized syntax [1], EAI systems also offer functions for object and process integration [19].

Web services and EAI are mutually complementary rather than competing approaches [28]. Whereas EAI systems are used primarily in the intra-organizational field, the high level of standardization in the case of web services makes them suitable for inter-organizational applications. Here, the use of standards which are accepted at an inter-organizational level can obviate the need for proprietary EAI adapters.

\section{Process Portals in the Automobile Group}

With just over a million vehicles produced in 2002, the Automobile Group ranks among the world's largest automobile manufacturers. In the year 2000 a board resolution was passed to implement e-Business strategy in the IT architecture which currently encompasses 28 programs. Major issues are continuous optimization in the product creation process and acceleration of the customer-oriented sales and production process. In future, the corporation wants to provide customers with all services, which it makes available either internally or externally, through a total of four portals: one employee portal (B2E), one supplier portal (B2B), one end customer portal (B2C) and one distributor portal (B2D). 


\subsection{Architecture}

'Architectures and Frameworks', a department belonging to the corporate IT organization, is responsible for designing and delivering architecture patterns for the purpose of defining uniform standards. The department defines architecture patterns as generic architectures which are composed of logical, manufacturer-neutral software modules. The Automobile Group documents architecture patterns for different types of software such as e.g. portals, CRM, EAI etc. The architecture pattern for portals is defined in a portal rule book (see Table 3). This rule book encompasses all the requirements for setting up a master process portal in the corporation and shows the respective consequences for the integrated company portals. On the basis of this rule book the Automobile Group can derive direct projects such as e.g. the definition of standardized templates (presentation), the establishment of a central single sign-on system (security) etc. for all portals.

\begin{tabular}{|c|c|c|}
\hline Portal Functions & $\begin{array}{l}\text { Process Portal } \\
\text { Requirements }\end{array}$ & $\begin{array}{c}\text { Rules for the } \\
\text { Company Portals }\end{array}$ \\
\hline Presentation & $\begin{array}{l}\text { Definition of central } \\
\text { design guidelines to } \\
\text { ensure conformity } \\
\text { with Corporate Iden- } \\
\text { tity requirements. } \\
\text { Common use of } \\
\text { layout modules in } \\
\text { all sub-portals. }\end{array}$ & $\begin{array}{l}\text { - Use of standardized } \\
\text { templates based on } \\
\text { XML. } \\
\text { - Appointment of a } \\
\text { contact person for } \\
\text { the definition of de- } \\
\text { sign guidelines. }\end{array}$ \\
\hline Navigation & $\begin{array}{l}\text { Consistent naviga- } \\
\text { tion irrespective of } \\
\text { the underlying por- } \\
\text { tal. }\end{array}$ & $\begin{array}{l}\text { - Uniform assignment } \\
\text { of roles and content } \\
\text { plus a central portlet } \\
\text { repository for second } \\
\text { level and portlet } \\
\text { navigation. }\end{array}$ \\
\hline Interaction & $\begin{array}{l}\text { The process portal } \\
\text { should support dif- } \\
\text { ferent interaction } \\
\text { mechanisms de- } \\
\text { pending on the de- } \\
\text { vice used. }\end{array}$ & $\begin{array}{l}\text { - Use of a central } \\
\text { portal gateway for all } \\
\text { devices. } \\
\text { - In order to replicate } \\
\text { data for asynchro- } \\
\text { nous pull mecha- } \\
\text { nisms the respective } \\
\text { standards must be } \\
\text { supported and the } \\
\text { applications used } \\
\text { must have replication } \\
\text { capability. }\end{array}$ \\
\hline Personalization & $\begin{array}{l}\text { As the process por- } \\
\text { tal unites employee, } \\
\text { supplier and cus- } \\
\text { tomer portals, it } \\
\text { must offer cross- } \\
\text { instance possibilities } \\
\text { for pull and push } \\
\text { personalization. }\end{array}$ & $\begin{array}{l}\text { - Pull personalization } \\
\text { requires a uniform } \\
\text { role model. } \\
\text { - The basis for the } \\
\text { push personalization } \\
\text { is a profiling engine } \\
\text { which evaluates data. } \\
\text { Central master data } \\
\text { have to be defined } \\
\text { for this purpose. }\end{array}$ \\
\hline
\end{tabular}

\begin{tabular}{|c|c|c|}
\hline Security & $\begin{array}{l}\text { - Single authentica- } \\
\text { tion in the process } \\
\text { portal without the } \\
\text { portal user having to } \\
\text { log on again when } \\
\text { entering another } \\
\text { portal. } \\
\text { - Automatic authori- } \\
\text { zation (single sign- } \\
\text { on) for all applica- } \\
\text { tions connected to } \\
\text { the portal and as- } \\
\text { signed to the portal } \\
\text { role. }\end{array}$ & $\begin{array}{l}\text { - Use of the same } \\
\text { authentication data } \\
\text { source or data map- } \\
\text { ping between the au- } \\
\text { thentication in- } \\
\text { stances by a higher } \\
\text { level central in- } \\
\text { stance. } \\
\text { - In the case of inte- } \\
\text { gration using frames, } \\
\text { authorization can } \\
\text { remain decentralized. } \\
\text { Integration through a } \\
\text { central portlet reposi- } \\
\text { tory requires a har- } \\
\text { monized authoriza- } \\
\text { tion concept. }\end{array}$ \\
\hline Administration & $\begin{array}{l}\text { - Comprehensive role } \\
\text { model through the } \\
\text { standardization of } \\
\text { employee and or- } \\
\text { ganization master } \\
\text { data. } \\
\text { - Consistency of roles } \\
\text { to be secured by de- } \\
\text { fining macro and } \\
\text { micro-roles. }\end{array}$ & $\begin{array}{l}\text { Discontinuities in the } \\
\text { role model between } \\
\text { sub-portals and back- } \\
\text { end systems must be } \\
\text { bridged by the sub- } \\
\text { portal. } \\
\text { - Position sub-portals } \\
\text { in the overall role } \\
\text { concept by defining } \\
\text { micro-roles and as- } \\
\text { signing them to } \\
\text { macro-roles. }\end{array}$ \\
\hline Integration & $\begin{array}{l}\text { - Develop a central } \\
\text { portlet repository } \\
\text { that is an integral } \\
\text { part of a central se- } \\
\text { curity concept and } \\
\text { role model. } \\
\text { - Portlets should be } \\
\text { publicized as web } \\
\text { services which can } \\
\text { then be integrated } \\
\text { into further sub- } \\
\text { portals without an- } \\
\text { other physical im- } \\
\text { plementation. }\end{array}$ & $\begin{array}{l}\text { - No redundant port- } \\
\text { lets to be used. } \\
\text { - Appointment of a } \\
\text { department or busi- } \\
\text { ness unit to be re- } \\
\text { sponsible for each } \\
\text { portlet. } \\
\text { - When integrating } \\
\text { sub-portals the portal } \\
\text { initiator should en- } \\
\text { sure that existing } \\
\text { standardized integra- } \\
\text { tion patterns and in- } \\
\text { terfaces are used. }\end{array}$ \\
\hline
\end{tabular}

Table 3. Rule Book for Portals

\subsection{Integration}

The Automobile Group wants to achieve as high a level of standardization as possible in the networking of intra-organizational and inter-organizational processes through a harmonized integration architecture. Since no accepted method is currently available for integrating IS, the corporation defined 'integration patterns' which are intended to facilitate standardized integration. While IT has already been using integration patterns of this kind for some time now [11], this term has only recently appeared in publications in the field of information management (cf. e.g. [29]). At Automobile Group, a procedural model for the definition of integration patterns entails three steps. 


\section{Step 1: Analyse the Applications to be Integrated}

As a first step, the Automobile Group distinguishes between process-oriented business applications such as ERP or CRM systems and horizontal applications such as e.g. groupware applications. While the former supply structured data, groupware systems fall into the category of unstructured data. Another important distinction between the applications to be integrated into the portal relates to the web capability of the application and differentiates between non-web-capable, web-enabled and native web applications [22] (see Table 4).

In the Automobile Group, all applications are integrated into portals using HTTP, for example. In addition, the application to be integrated must supply XML data as this is the only way in which consistency can be checked and the application remains unaffected in the case of layout changes. Finally, the HTML output uses an XSLT template. This has the advantage that the presentation functionality stays in the portal.

\begin{tabular}{|l|l|l|l|}
\hline $\begin{array}{r}\text { Application } \\
\text { Type }\end{array}$ & \multicolumn{1}{|c|}{$\begin{array}{c}\text { Non-web- } \\
\text { capable } \\
\text { Applications }\end{array}$} & $\begin{array}{l}\text { Web-enabled } \\
\text { Applications }\end{array}$ & $\begin{array}{l}\text { Native } \\
\text { Web Appli- } \\
\text { cation }\end{array}$ \\
\hline Characteristics & $\begin{array}{l}\text { Not accessible } \\
\text { using web } \\
\text { technology, e.g. } \\
\text { mainframe } \\
\text { applications }\end{array}$ & $\begin{array}{l}\text { Proprietary } \\
\text { HTML code, } \\
\text { e.g. SAP Inter- } \\
\text { net application } \\
\text { components }\end{array}$ & $\begin{array}{l}\text { XML-based, } \\
\text { e.g. Java } \\
\text { Beans }\end{array}$ \\
\hline Integration level & $\begin{array}{l}\text { Only possible } \\
\text { by modifying } \\
\text { the application }\end{array}$ & $\begin{array}{l}\text { Low, via } \\
\text { iFrame }\end{array}$ & $\begin{array}{l}\text { High, via } \\
\text { pasthrough } \\
\text { XML or } \\
\text { parsed XML }\end{array}$ \\
\hline $\begin{array}{l}\text { Extent of modifi- } \\
\text { cations }\end{array}$ & High & Low & Low \\
\hline Time \& effort & High & Low & Low \\
\hline Performance & $\begin{array}{l}\text { Virtually un- } \\
\text { changed }\end{array}$ & Good & Very good \\
\hline Maintainability & Poor & Average & Very good \\
\hline Risk & Low & Average & Low \\
\hline
\end{tabular}

Table 4. Characteristics of Application Types to be Integrated

\section{Step 2: Develop the Integration Patterns}

The Automobile Group uses the product TIBCO PortalBuilder as portal application. With the TIBCO PortalBuilder, there are a total of 13 different portlet types available as well as three different EAI types (TIBCO Rendezvous RT, TIBCO ActiveEnterprise and TIBCO Rendezvous) for integrating horizontal and vertical applications [34] (see Table 6, Table 5). First of all, on the basis of the interfaces all the applications to be integrated into the portal and all the possible integration technologies (portlets, EAI and web services) are entered in a matrix and each integration technology matched with each application. The individual technologies are assessed according to suitability. This assessment process was based on the Automobile Group's existing B2E portal. For integration patterns which are not yet available in the B2E portal, discussions were held with the people responsible to determine the respective requirements.

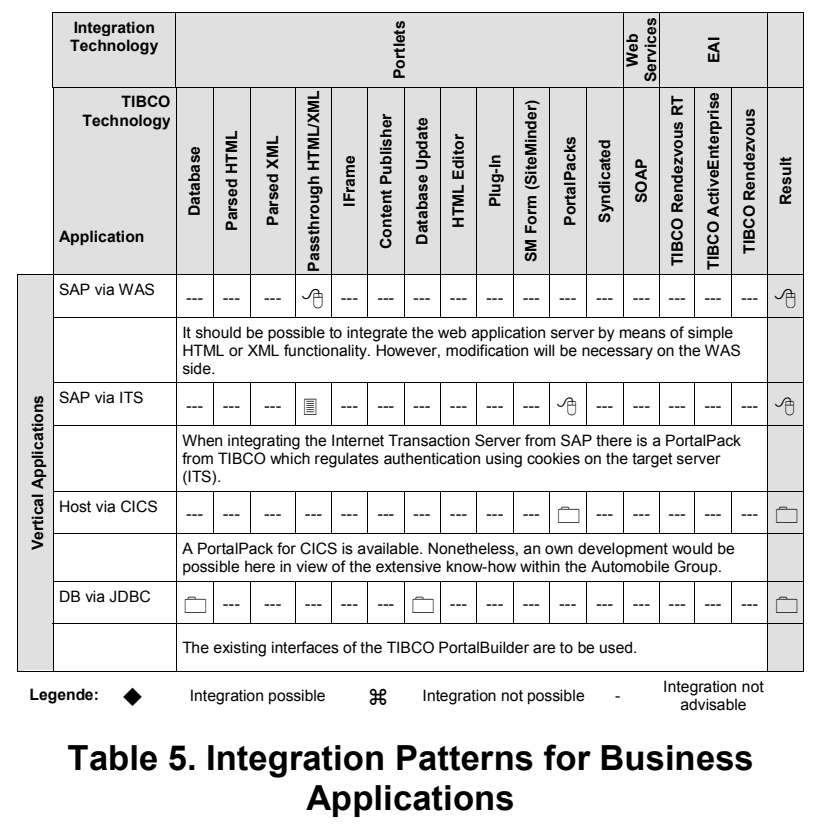

The result of the assessment can be seen in the last column headed 'Result'. The ideal integration pattern for each application is entered here as the result. Thus, integration using passthrough HTML/XML is suitable for CMS, for example, while integration using parsed HMTL, parsed XML and Database or Database Update is possible but not so good or could only be realized with more time and effort. Cells with three dashes (---) are ruled out. For each integration pattern the Automobile Group enters the characteristics in a separate column under the assessment.

\section{Step 3: Implement the Integration Architecture}

In a third step, the Automobile Group specifies the integration architecture from the derived integration patterns by detailing each integration pattern with all the modules involved. This entails on the one hand specifying the portlets for standard software integration, but on the other, as shown in the above example of the integration samples, may also mean integrating the old applications into the portal. Here, too, the interfaces have to be specified and programmed. 


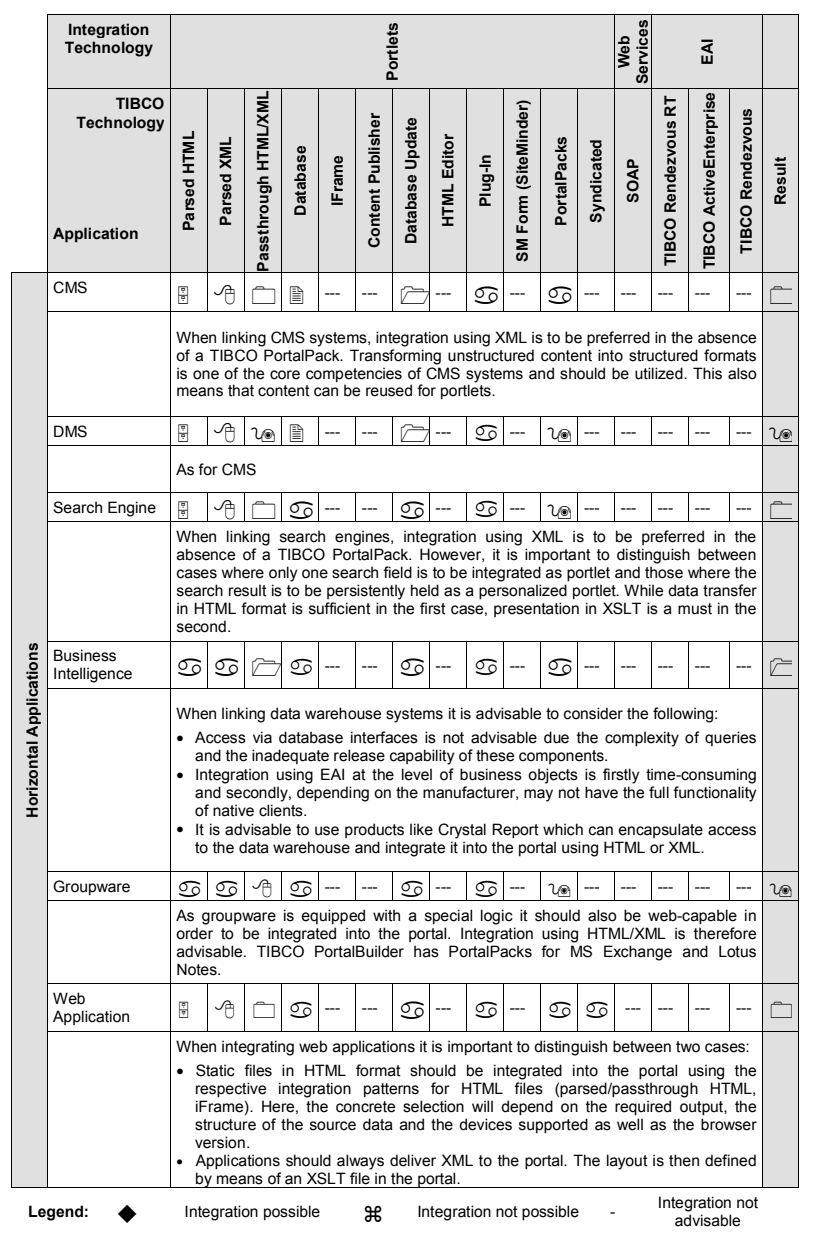

Table 6. Integration Patterns for Horizontal Applications

\subsection{Benefits}

The Automobile Group quantifies the benefits of the architecture on the basis of the potentials and metrics determined in Section 1.2 (see Table 7). Over the next three years the corporation is planning 30 portal projects. Inhouse experience shows that a project of this kind costs on average EUR $0.5 \mathrm{~m}$. Current projects in the Automobile Group reveal that a clearly defined portal architecture has reduced the initial outlay and follow-on costs for these projects by an average of $20 \%$, which according to the table below should lead to savings totaling EUR $3 \mathrm{~m}$ in the future. The costs of defining the portal architecture can be classed as low in comparison.

\begin{tabular}{|l|l|}
\hline $\begin{array}{l}\text { Critical Suc- } \\
\text { cess Factors }\end{array}$ & \multicolumn{1}{c|}{ Potentials } \\
\hline Time & $\begin{array}{l}\text { The portal architecture shortens the implementation } \\
\text { period for each individual project as the require- } \\
\text { ments are already defined. In addition, the number of } \\
\text { project delays falls since the experience gained from } \\
\text { previous projects is transparent for all. }\end{array}$ \\
\hline Costs & $\begin{array}{l}\text { Price reductions are to be expected in hardware and } \\
\text { software as a result of the portal architecture because } \\
\text { Procurement can purchase higher volumes due to the } \\
\text { fact that products are stipulated. }\end{array}$ \\
\hline Quality & $\begin{array}{l}\text { As a result of the central portal architecture the de- } \\
\text { partment 'Architectures and Frameworks' achieves a } \\
\text { uniform corporate design for the portals. This means } \\
\text { that customers recognize that the same corporation is } \\
\text { involved in the different portals. } \\
\text { The standardizations stipulated by the portal archi- } \\
\text { tecture lead to reduced maintenance costs due to the } \\
\text { lower number of different release statuses and inter- } \\
\text { faces. }\end{array}$ \\
\hline Flexibility & $\begin{array}{l}\text { A standardized IS architecture means greater flexi- } \\
\text { bility in depicting changes in the customer process. } \\
\text { As a result the customer can incorporate new appli- } \\
\text { cations more rapidly, for example. }\end{array}$ \\
\hline
\end{tabular}

Table 7: Benefits at Automobile Group

\section{Summary and Outlook}

Process portals integrate the companies in a business network via the services of the customer process. In order to realize this inter-organizational service integration companies must develop open architectures capable of grouping together in one portal heterogeneous applications which are distributed across various organizations. The architecture model presented here offers a framework for the different functions of a portal and outlines three integration technologies. It thus extends existing approaches from literature and practice to include an interorganizational view of the architecture and at the same time covers all three architecture layers, namely presentation, application functionality and data. The example of the Automobile Group shows how a rule book can serve the purpose of standardizing portal functions and how the corporation deals with portal integration.

Both the architecture model and the methodology for portal integration have been validated yet again in a second project in the telecommunications sector. Two critical success factors for implementation of the architecture model are evident from both projects. These are first of all central coordination and communication of the architecture e.g. by an IT department, and secondly a high degree of reuse to achieve economies of scale. Alongside these critical success factors, three topics for further research were identified in additional portal projects at DaimlerChrysler, Robert Bosch and Hoffmann-La Roche. 
The first relates to the validation of the model in further empirical projects. This can help research and practice to verify the potentials as well as to refine the metrics. The second topic involves reflecting new approaches to architecture taken from literature and practice. The architecture model developed can help to analyze the content of supplier-based architectures independently of marketing messages. A third topic concerns functional development of the architecture model. Particularly worth mentioning in this context are process-oriented approaches such as e.g. the Cross Applications (xApps) from SAP [9]. These applications involve a set of portlets which are specially geared to inter-organizational collaboration for a specific customer activity.

\section{References}

[1] Bernstein, P. Middleware: A Model for Distributed System Services. Communications of the ACM, 39, 2 (1996), 86-98.

[2] Bristow, P.; Dickinson, C.; Duke, S.; Henry, S., and Makey, P. Enterprise Portals: Business Application and Technologies. East Yorkshire: Butler Group, 2001.

[3] Chan, M.F.S., and Chung, W.W.C. A Framework to Develop an Information Portal for Contract Manufacturing. Production Economics, 75, 3 (2002), 113-126.

[4] Checkland, P., and Holwell, S. Action Research: Its Nature and Validity. Systemic Practice and Action Research, 11, 1 (1998), 9-21.

[5] Davydov, M.M. Corporate Portals and e-Business Integration. New York (NY): McGraw-Hill, 2001.

[6] Dias, C. Corporate Portals: A Literature Review of a New Concept in Information Management. International Journal of Information Management, 21, 4 (2001), 269287.

[7] Diaz, A.L.; Fischer, P.; Leue, C., and Schaeck, T. Web Services for Remote Portals (WSRP). IBM Corp., http://www-106.ibm.com/developerworks/library/wswsrp/, 15.07.2003.

[8] Färber, G., and Kirchner, J. mySAP Technologie: Einführung in die neue Technologie-Plattform der SAP. Bonn: Galileo, 2002.

[9] Färber, G., and Kirchner, J. mySAP Technology Roadmap. Bonn: Galileo, 2003.
[10] Ferguson, D.F., and Kerth, R. WebSphere as an ebusiness Server. IBM Systems Journal, 40, 1 (2001), 25 45 .

[11] Gamma, E.; Helm, R.; Johnson, R., and Vlissides, J. Design Patterns - Elements of Reusable Object-Oriented Software. Reading (MA): Addison Wesley, 1994.

[12] Gillet, F.E. Making Enterprise Portals Pay. Cambridge (MA): Forrester Research Inc., 2001.

[13] Goodyear, M. Enterprise System Architectures. Boca Raton (CA) etc.: CRC Press, 2000.

[14] Hildreth, S. Plug-and-Play Portal Standards on the Horizon. ebizq: The Insiders's Guide to eBusiness Integration, http://eai.ebizq.net/por/hildreth_1.html, 15.07.2003.

[15] IBM. Guide to Websphere Portal. Research Triangle Park (NC): IBM, 2002.

[16] Kalakota, R., and Robinson, M. e-Business 2.0: Roadmap for Success. Boston (MA): Addison Wesley Longman, 2001.

[17] Letson, R. A Closer Look at Portals and EAI. Transform Magazine, http://www.transformmag.com/db_area/ archs/2001/07/tfm0107f1.shtml, 15.07.2003.

[18] Linthicum, D.S. Enterprise Application Integration. Reading (MA) etc.: Addison Wesley Longman, 2000.

[19] Linthicum, D.S. B2B Application Integration: eBusiness-Enable Your Enterprise. Boston (MA) etc.: Addison Wesley Longman, 2001.

[20] McDonough, B. Worldwide Enterprise Information Portal Software Market Forecast and Analysis 20012006. Framingham (MA): International Data Corporation Research, 2002.

[21] Orfali, R.; Harkey, D., and Edwards, J. The Essential Client/Server Survival Guide. Chichester: Wiley \& Sons, 1997.

[22] Orfali, R.; Harkey, D., and Edwards, J. Client/Server Survival Guide. Chichester: John Wiley \& Sons, 1999.

[23] Österle, H. Enterprise in the Information Age. In Österle, H., Fleisch, E., Alt, R. Business Networking: Shaping Collaboration between Enterprises. Berlin etc.: Springer, 2001, 17-54.

[24] Ovum. Enterprise Portals: New Strategies for Information Delivery. London: Ovum Ltd, 2000. 
[25] Phifer, G. Portals in 2002: A Year of Major Change. Stamford (CT): Gartner Group, 2001.

[26] Plumtree. An Overview of Corporate Portal Technology and Deployment - Survey Results From Organizations That Have Deployed Corporate Portals. San Francisco: Plumtree Software, 2001.

[27] Roth, C. Simplified Approach to Portal Requirements Gathering. Stamford (CT): Meta Group, 2001.

[28] Samtani, G., and Sadhwani, D. EAI and Web Services. Web Services Architect, http://www. webservicesarchitect.com/content/articles/samtani01.asp, 15.07.2003.

[29] Sandoe, K.; Corbitt, G., and Boykin, R. Enterprise Integration. Chichester: John Wiley \& Sons, 2001.

[30] Schaeck, T. Web Services for Remote Portals (WSRP). Organization for the Advancement of Structured Information Standards, http://www.oasis-open.org/ committees/wsrp/documents/wsrp_wp_09_22_2002.pdf, 3.10.2003.
[31] Schulte, R. Three-Tier Computing Architectures and Beyond. San Jose (CA): Gartner Group, 1995.

[32] Sleeper, B., and Robins, B. The Laws of Evolution: A Pragmatic Analysis of the Emerging Web Services Market. San Francisco (CA): The Stencil Group, 2002.

[33] Themistocleous, M., and Irani, Z. Benchmarking the Benefits and Barriers of Application Integration. Benchmarking: An International Journal, 8, 4 (2001), 317-331.

[34] Tibco. Tibco ActivePortal. Palo Alto (CA): Tibco Software, 2002.

[35] Walker, J., and Wilkoff, N. The New Enterprise Portal Imperative: Cut Costs. Cambridge (MA): Forrester Research, 2002. 